\title{
SOME OUTLOOKS ON CREATIVITY IN MATHEMATICS TEACHING
}

\author{
Hariz Agić ${ }^{1}$ \\ Sead Rešić
}

Institute for Pedagogy of Tuzla Canton

Department of Mathematics, Faculty of Sciences, University of Tuzla

\author{
Original scientific papers
}

Received: 06.07.2015

Accepted: 01.09.2015
UDC: $371.135: 159.954$

371.12.011.3-051:51

371.3:51

\begin{abstract}
The role and significance of Mathematics in human life is very important and holds a special place in development of contemporary society. Creativity in Mathematics teaching largely depends on Mathematics teacher. Teacher is the one who creates emotional environment in the classroom and it is expected from him/her to create with the students a relationship of trust and mutual responsibility for the success of conducting the teaching process. Students need to be interested and activated to individually solve tasks and find solutions to set Mathematical problems, to solve tasks in different ways using various methods, so that everybody can find a way of coming to a solution. This is easy to say. In any case, creativity as a competence holds a significant place in the set of key life competencies. Only teachers can answer questions whether Mathematics classes are creative, interesting, or acceptable for students. This paper will contain certain theoretical viewpoints about creativity in general, creative Mathematics teaching, relation towards creativity at school and outside. Research has shown that examinees (teachers of class and subject teaching in elementary and secondary schools) believe that they did not receive a good background during their university studies for strengthening teaching creativity. It transpired that creativity, as opposed to student and teacher, is appreciated less at the school and education system levels. Teachers (of all levels) have shown high level of agreement regarding the need for turnover in relation to creativity in Mathematics teaching, which would guarantee increase of interest of students for Mathematics.
\end{abstract}

Keywords: creativity, creative Mathematics teaching, creative teacher

\section{INTRODUCTION}

We are witnesses that creativity is a common topic of conversation, but little is done to ensure its existence and development. Creativity is a major topic of many a seminar. By organizing seminars, organizers often believe that that is enough to change behavior from stereotypical to creative. Many people talk about creativity, teach about it, while in practice they do not behave as they speak. The questions is whether creativity can learned, if there are no other preconditions for its existence. Said from experience, nothing significant is learned during university studies. From today's perspective, evoking memories from student days mostly comes down to unusual behavior of pro-

\footnotetext{
${ }^{1}$ Correspodence to:
}

Hariz Agić, PhD, Institute for Pedagogy of Tuzla Canton

E-mail: agich59@hotmail.com fessors. Young teachers - beginners do not engage in adventures with unusual behavior or employing creativity in class. This was sustainable in the time where knowledge sources were scarce, there was no Internet, etc. Today's students and those from about 30 years ago do not have the same outlooks, needs, interests or behavior. Traditional teaching is not suitable for students any more. It is boring to them. Teachers and education authorities are facing the problem of students' learning crisis more and more. There is no great use in blaming others for this: parents, influence of the street, media, Internet, state of society, etc. 
Teachers' belief that this is not their problem is unsustainable. Education workers often talk to each other about their creative endeavors which were satisfactory for both them and students. A more creative relation toward creativity would be more present among teachers if creativity, as a value, was more appreciated at school. This paper will possibly shed light on some outlooks on creativity through authors' theoretical overviews. It would be frivolous to think that this will make readers more creative. Results of the research conducted among Mathematics teachers of class and subject teaching in elementary and secondary schools will be presented.

\section{Creativity as a key competence}

In $2006^{2}$, the European Union issued a document about key competencies in work market. Agency of preschool, elementary and secondary education of Bosnia and Herzegovina (APOSO) conducted a process of adjusting the European referential frame of key competencies in Bosnia and Herzegovina, with participation of representatives from Ministry of education, institutes for pedagogy and pedagogical faculties. Competencies, according to the European frame, are literacy in mother language, communication in foreign languages, mathematical and informatics literacy, learning how to study, social and civic competencies, self-initiative and entrepreneurship competencies, and cultural consciousness, while, which is interesting for the topic of this paper, two competencies are added for conditions in Bosnia and Herzegovina: creative-productive and body and health competencies (www.ceppei.ba). Creative-productive competence is generated from several areas: (1) Developing complex thinking: summarizing, generalizing, support for employing higher cognitive abilities, such as analysis, synthesis, evaluating, using critical thinking (differentiating between facts and opinions, argumenting theses); applying logical structuring and sequencing arguments while adopting and forming a foreign language and learning linguistic laws; (2) Developing creativity and need for expression and the feeling for aesthetic values: producing and connecting various ideas, creating assumptions and various products; (3) Developing openness for various cultural expression and readiness for developing own creativity and ability for expression: ability to tolerate opposite ideas; drawing conclusions independently; developing a positive attitude and being willing to relativize own point of view and value system, developing ability for vari-

${ }^{2}$ Recommendation of the European Parliament and of the Council of 18 December for lifelong learning (2006/962/EC) ance regarding settled behavior toward other cultures; (4) Support for curiosity, wish for new knowledge: enabling expression of thoughts, ideas, emotions; developing the ability to observe, participate and integrate new experiences and readiness to change the previous ones $^{3}$. All key competences support each other. When it comes to creative-productive competence, it can be said that it is closely related to entrepreneurial, informatic, and especially mathematical competencies. Looking at guidelines of creative-productive competence, it can be seen that Mathematics is the most suitable for its development.

In the following text, certain theoretical hypotheses will be stated which relate to the term creativity, relation toward it in society and school, etc. There are many definitions of creativity, where authors seemed to race each other in defining the term.

\section{Defining creativity}

There is no unique and authoritative point of view or definition of creativity. Some authors believe that creativity means looking at the world differently. Others will claim that it means creating links where they do not obviously exist. Some believe that creativity means creating that which still does not exist, while others define it as making something up, experimenting, development, taking risks, breaking rules and entertainment (http://www.apm.hr/skola).

Unlike most phenomena in psychology, there is no standardized technique for measuring creativity. Despite that and the nature of creativity itself, "entire industries rose from the chase for creative ideas and development of creative techniques. This mysterious phenomenon, albeit undeniably important and constantly visible, seems to lie above the reach of scientific research". ${ }^{4} \mathrm{w}$

As previously mentioned, there is no unique definition of creativity. Some authors (Grković, 2012) focus on creativity by defining it as "thought processes which lead to problem solving, ideas, artistic forms, theories or products that are unique and new", while others (Kadum, 2011) focus on creativity as human potential present in every human being, which enables people to create new ideas and products in a completely new way, pointing to "creativity as potential in human beings, which is present from birth until very old age, that is, death" and that "creativity comes to life as a form of resistance against all that is traditional, usual and unoriginal.

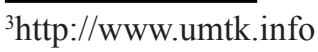
${ }^{4} \mathrm{http} / / /$ hr.wikipedia.org/wiki/Kreativnost
} 
It includes an array of abilities which need to be uncovered, developed and encouraged in every child" (Kadum, 2011:3). Mathematics presents excellent ground for uncovering and strengthening those abilities.

There used to be stereotypes that creative people are born as such. This especially applied to Mathematics students. Those students who deal with original problem solving, finding alternative solutions, who are Mathematics enthusiasts, are labeled as nerds, fanatics, weird, oddballs, in their own world, etc. However, when it comes to creativity in general, the opinion (Grković, 2014) prevails that "every average person can be limitlessly creative if he/she wants it". According to the same author, "small children are incredibly creative", but "traditional upbringing and education completely presses down creativity children acquired before starting school" (Grković, 2014).

Such an inert education system managed to turn the outlook on creativity in community from being a value, even though it is connected to many other values, such as entrepreneurship, problem solving, etc.

\section{Creativity in society}

Creativity in the social context of Bosnia and Herzegovina does not claim the place which belongs to it. It is mostly identified as creating new and original, artistic and technical characteristics, which enable realization of artistic creation, encouraging new ideas, solving concrete problems, unusual expression, etc. It has become clear that creativity cannot be learned through realization of certain cultural activities. It requires much more. In the social context of Bosnia and Herzegovina, creativity is adequately placed among strategies, which do not bind anyone, or is visible through realization of EU projects related to certain problems of creativity in implementing entrepreneurship in education, for example. These projects deal with pilot schools with clear goals, the most important being the goal which implies successful completion of the project that will bring a lot of income. Projects are usually completed with final conferences, picturesque final documents that are often prepared in advance. Of course, this is not a rule, but it is an opinion of many well-informed people from education. There is presence of one of Balkan syndromes in our society, that being that creative (and successful) people are talked about after their death. Be that as it may, a lot of time will pass be- fore there are discussions in our society about topics such as "creativity as actuator of society" or "creativity and innovation for better society", which are the subject of debate in academic and social community in neighboring countries. The good news is that creativity is in the focus of non-government sector, which takes the credit for creativity being well present in pre-school education, class teaching and in rare cases in subject teaching. These attempts in establishing critical mass for creating favorable social environment where it will gain a more favorable position, because "environment in society may have an effect on the level and frequency of creative behavior" (Amabile, Conti, Coon, Lazenby \& Herron, 1996: 1155). Society which contributes to creative work, stimulates it in various way, values and evaluates it, will most certainly create favorable conditions for development of creativity. We are witnesses that, within society, in almost all its segments, everything is put into clichés, procedures, patterns, where creativity and innovation is lost. In the context of Bosnia and Herzegovina, schools remain as places where, to a certain degree, creativity is talked about as a value. Society which contributes to creative work, stimulates it in different ways, values and evaluates it, will create good conditions for development of creativity.

\section{Creativity in school}

It is well known that school and relations within school represent a projection of relations within the entire society. Education policies agree with policies in the community when it comes to the relation toward values and relationships within.

According to Grković (2014), traditional (regular) education system teaches us to dominantly think logically (linear). This means that we are focused on lists, sequences, previous experiences, the recognized, expected and safe. Gustavson (1955) justifies this and claims "that people are afraid of drastic innovations, partly because they prefer what is familiar to them, and partly because interests of majority are mostly connected to the present state" (cited in Stoll \& Fink, 2000: 19). According to these authors, schools are conservative institutions which traditionally resist changes and seek ways to preserve continuity in order to survive without earthquakes.

${ }^{5}$ http://www.unizg.hr/index.php, Sveučilište u Zagrebu, Okrugli stol "Kreativnost kao pokretač društva", 04.03.2015. 
The issue here are changes in school, which are closely related to presence of creativity of all participants in education. Fulan (2001:31) believes that "changes do not happen without disorder as side effect", further explaining this by claiming that "greater understanding of changes does not manifest through talking about innovations, but through concrete innovations". Signals that arrive from the business sector and talk about creative managers who amass large profit, initiate many projects in schools, focused on creativity in school. Schools which value creativity more are recognized in local community. They are involved in many projects and non-government sector often visits them. They are known for employing various teaching methods, making and using teaching aids, different approach to work with parents and other partners from school environments. As is the case with everything else, relation toward creativity depends on teachers.

\section{Creative teacher}

Creativity in teaching presents constant search for innovations in the education process, for new solutions, developing new and improving existing teaching programs. Creativity in school directly depends on teachers' readiness to apply it in all segments of the teaching process. Creative Mathematics teacher will within motivation part of the class connect the subject matter with concrete life situations. He/she will apply various methods and forms of work, from individual, pair work, group work, to using heuristic method, project and experimental teaching, etc. Such a teacher will be a role model for many students in creation of their own professional development. Contemporary age sets in front of teachers new tasks:

Traditional teaching cannot bear demands of modern society, which asks that the individual be more creative, solve problems successfully, possess more than mere knowledge of facts, but use them, be able to work in a team and manage different environments and different problems (Salihović \& Teparić, 2011).

In contemporary age, it is necessary to enable students for individual and creative problem solving and convince them that amassing knowledge and facts is not enough for creation of a competent student for upcoming times, times of changes. Here are key characteristics which would adorn such students: openness, readiness for criticism, initiative, motivation, curiosity, self-confidence, broad interests, readiness for changes (Grković, 2012). Having this in mind, teachers are exposed to great challenges. There is an occurrence in schools where creativity is not part of school culture to sufficient extent, of creative teachers to be looked upon as strange, eccentric, reformators and persons who disturb traditional ways of work in "good old school". Is teachers' creativity considered as a value in school? Did they during their university studies and professional development have the opportunity to strengthen their creative potential? Answers to these questions would shed light on the relation to teachers' creativity. In this paper, results of research among teachers about these subjects will be presented. Some research shows what makes a teacher creative. Hallman (1970) offers a list of ideas which describe a creative teacher.

Creative teachers:

- encourage individual learning and activity in students, encourage them to express themselves, experiment, construct hypotheses;

- establish non-authoritarian class climate - relaxing conditions enable creative activities;

- encourage excessive studying, so that students become saturated with information, impressions and meaning; excessive studying encourages creative work by enabling students to depart from teaching materials, thus making the curriculum more flexible and suitable for new constructs;

- rehearse processes of creative thinking, encourage students to find new connections between data, create associations and use imagination;

- delay giving grades, do not limit exploration attempts by offering results or provide solution; show less concern about mistakes and help students understand that mistakes are to be expected, even necessary;

- support intellectual flexibility in students, encourage them to change their point of view in order to avoid uniformity while solving tasks;

- encourage self-evaluation of accomplishments and individual's development because creativity implies independence, responsibility and permanent selfevaluation;

- help students become more sensitive to social, personal and school problems;

- know how to use and set questions; everything begins with questions which should be open, sensible and students are able to answer them;

- offer students an opportunity to peruse materials, ideas, concepts, tools and structures...; encourage creativity by helping students understand processes in progress;

- help students overcome frustrations and failure;

- direct students toward looking at a problem as a whole, instead of a separate part; building as integrative whole gives directions for creative processes (in Pinter, Krekić \& Ivanović, 2013:293-294). 
The above-mentioned list of ideas is very demanding. This only speaks of importance and complexity of teacher's creative work. It is a very difficult process to satisfy all those demands. However, teachers are expected to be creative, recognize creative students, follow their further development and flow of creativity, as well as to create positive atmosphere for developing creativity. It is of great importance that teachers support students in their attempts to explore, discover and stay interested. One of the indicators of a creative teacher are his/her creative students. According to Kadum (2011: 5), "teacher's creativity is recognized firstly in his/her preparation for conducting classes". "There is no creativity without good knowledge about teaching material, choosing the most suitable methods and forms of work, using available aids while elaborating the subject matter" (Ibid, 2011: 5).

Teachers' creativity is very much welcome in schools in Bosnia and Herzegovina, it is even defined in school documents, but encouraging creativity remains incomplete and depends on personal involvement of teachers as individuals. This usually remains on a declarative level, and, for the most part, depends on the teacher. This should not be surprising, since evaluating quality of teachers involves measuring their creativity to a very small extent or not at all. The reason for this is that creativity cannot be defined uniformly and it is difficult to evaluate the quality of creative work. Nevertheless, knowledge gains on its value only with creativity. This is why it is necessary to encourage creativity in elementary and secondary education, which demands additional teacher competencies.

Mathematics teachers should, more than anyone else, understand the importance of Mathematics and Mathematical education, as well as tasks accomplished through it. Students should not be burdened with unnecessary efforts of arid task solving. On the contrary, students need to be interested and activated to individually solve tasks and find alternative solutions to set Mathematical problems. Therefore, "they must be motivated to solve tasks in different ways, using various methods, so that everyone can find a path to solution" (Kadum, 2011: 8).

Creativity is not supported only with the most contemporary teaching technique and technology, well-planned teaching programs and satisfactory number of students in the classroom. If the teacher does not sufficiently support creativity, it is bound to fail. Creative teachers do not find numerous difficulties they face or lack of necessary logistics reason enough not to be creative. On the contrary, creativity is often inspired by poor equipment in schools. This proved to be correct during the war, when teachers, despite poverty, successfully organized and conducted the education process. It transpired that, regardless of numerous difficulties they face, teachers can do a lot to create a creative atmosphere and contribute to encouraging creativity in students.

\section{How to encourage creativity?}

In recent several years, the focus of Mathematics seminars has been the issue of crisis in students' learning, strengthening motivation in Mathematics teaching, application of various methods, strengthening interdisciplinarity and connecting teaching content with experiences from the environment. It has been said that ideas teachers have are a great treasure, which needs to be exchanged with other teachers. The role of Association of Mathematics teachers has been strengthened as well, with the aim of organized exchange of useful ideas.

Some more ideas that may encourage creativity are presented as follows ${ }^{6}$ :

- Read a lot, it is useful to study ideas and projects of intelligent people. Case studies and biographies are very inspiring. Read biographies of successful people and try to understand what procedures they used to train their brain.

- Use your creative mood, when you are in a creative phase, use it to the maximum. Let good ideas appear without limits.

- Take notes of your ideas, when a brilliant idea appears, make sure it stays, write it down and try to realize it as quickly as possible. Just like fruit, ideas are best fresh.

- Construct creative environment, sometimes all we need is a change of conditions where your thoughts will have freedom and need for questioning.

- Skip the generation gap, children's thoughts are always fresh and unburdened with social and societal circumstances and limitations. Talking with children will help you enter a simple, and yet untrammeled world. Ask them for opinion about a problem you are trying to solve. On the other hand, you should also consult the older generation.

- Follow what you know, sometimes it is necessary to stick to your area of expertise.

- Expand your previous ideas, ideas are like a computer. Every once in a while they need to be upgraded and updated. Let your past ideas be a foundation and build on them. Improve them.

${ }^{6} \mathrm{http}: / / \operatorname{covermagazin} . \operatorname{com} /$ karijera.php? NID $=1770$, (05.03.2015) 
In this text, certain viewpoints have been mentioned, from first-hand experience, as well as from various theoreticians, about creativity as a very important phenomenon, especially in times ahead. We attempted to portray what the situation with creativity is in general, which implies the area of Mathematics teaching as well. In the application part, results of the research about outlooks on this subject from the point of view of our colleagues, teachers in class and subject Mathematics teaching in elementary and secondary school will be presented.

\section{RESEARCH}

Aim of research in this paper is to gather information about creativity, based on opinions of Mathematics teachers in subject teaching, Mathematics teachers in elementary and secondary schools about questions related to creativity, starting with their experiences with creativity during their undergraduate studies and specialization, creativity in school, in Mathematics teaching, up to recommendations for improving relation toward creativity in school.

Task of research is to ascertain the intensity of attitudes of Mathematics teachers in subject teaching and elementary and secondary school teachers about areas covering the relation to creativity:

the role of university education in strengthening creativity of future subject class and Mathematics teachers,

relation toward creativity in school and in Mathematics teaching,

define the proposal of measures which would improve the status of creativity in education.

H1: creativity in schools does not have appropriate support for development,

$\mathrm{H} 2$ : relation toward creativity is more favorable in elementary, than in secondary schools in Tuzla Canton.

The sample of participants in this research was purposeful, since teachers of class and subject teaching were taken into account during a seminar organized by Institute for Pedagogy of Tuzla Canton in December 2014, which included 101 class teachers, 47 Mathematics teacher in elementary school, and 42 teachers in secondary schools in Tuzla Canton. This is a three-part sample including examinees from all schools in Tuzla Canton, who will guarantee that, based on their viewpoints, they reflect the existence of the very same viewpoints and opinions of all class and subject teachers of Mathematics "as the basic group or population" (Mužić, 1979:534), with expectancy of "being able to learn the most, that is, acquire the most useful information" (Merriam, 1998:61).

In this research, a survey was used. A questionnaire research was conducted among teachers from all schools in Tuzla Canton who attended the seminar for teachers of class subjects and Mathematics teachers, who filled the questionnaire and answered the posed questions. We believe that distribution of answers from examinees represents "distribution of behavior, thinking and attitudes in the basic group" (Ristić, 2006:350).

Survey was conducted through a Questionnaire with attitudes and Liker's descriptive scale of opinions with four levels of agreement with a statement (i.e. Very important, Important, Averagely important and Not important) (Mužić, 1979). Short, simple and unambiguous statements were chosen, and examinees gave their opinions by adding a cross sign to squares next to four offered answers (Bakovljev, 1997). Statements cover four areas. The first area contains four attributes which generate attitudes toward creativity in university education. The second area contains six attributes which examine attitudes toward the present state in relation to creativity in school. The third area contains six indicators that represent attitudes about creativity in Mathematics teaching. The fourth area, which contains six statements representing attitudes about proposals for improving relation toward creativity in school.

Limitations in research are connected to generalization. Since the sample in the conducted research is chosen randomly and spontaneously, it cannot guarantee as such that generalization is possible for wider population, that is, to the area of Bosnia and Herzegovina. This was not the intent of the research, but, references can certainly be drawn about certain aspects related to issues that cover relation toward creativity, which can be a basis for further research, which may ultimately cause improvement of status of this area. 


\section{Data analysis}

In this paper in data analysis, Average Value Method (AVM) was used, or, more precisely, the method of mean values (Walker, 2006, in: Agić, 2011).For its application, it was necessary to connect functionally the four-level Likert scale of evaluating attitudes with numeric values 1-4 (Grade 1 signifies the lowest, while grade 4 is for the highest level of satisfaction). After this, it was possible to calculate the arithmetic mean of values for intensity of attitudes about certain indicators for all three populations of the focus group. Acquired average values were used for comparative analysis of levels of expressed satisfaction of examinees about the same questions. Due to space limitations, the results will be presented only graphically. Therefore, the use of Average Value Method proved to be the most efficient in recording difference in viewpoints of observed populations. These differences, as will be presented, are sometimes very little, but still, they are differences.

\section{University education}

The first indicator was expressed as statement (a) In university studies there are subjects that taught us about creative teaching methods. The mean value of intensity of attitudes (teachers in class teaching $(\mathrm{R} / \mathrm{N})$ 2.25; Mathematics teachers in elementary schools (OŠ) 2.51; Mathematics teachers in secondary schools (SŠ) 1.83) signifies that satisfaction of examinees is below average (Graph 1). This is especially true for secondary school teachers, who claim that they did not have the opportunity at university to learn about creative approaches to teaching Mathematics.

Even greater dissatisfaction was shown in statement (b) Classes at the university I attended was creative and supported the use of creativity (R/N 2.1; OŠ 2.33; $\mathrm{SS}$ 1.61). The fall in average values of viewpoints continued in statement (c) Classes and exercises contained creative workshops and various teaching aids $(\mathrm{R} / \mathrm{N} 1.72 ; \mathrm{OŠ} 2.13$; SS̆ 1.48).

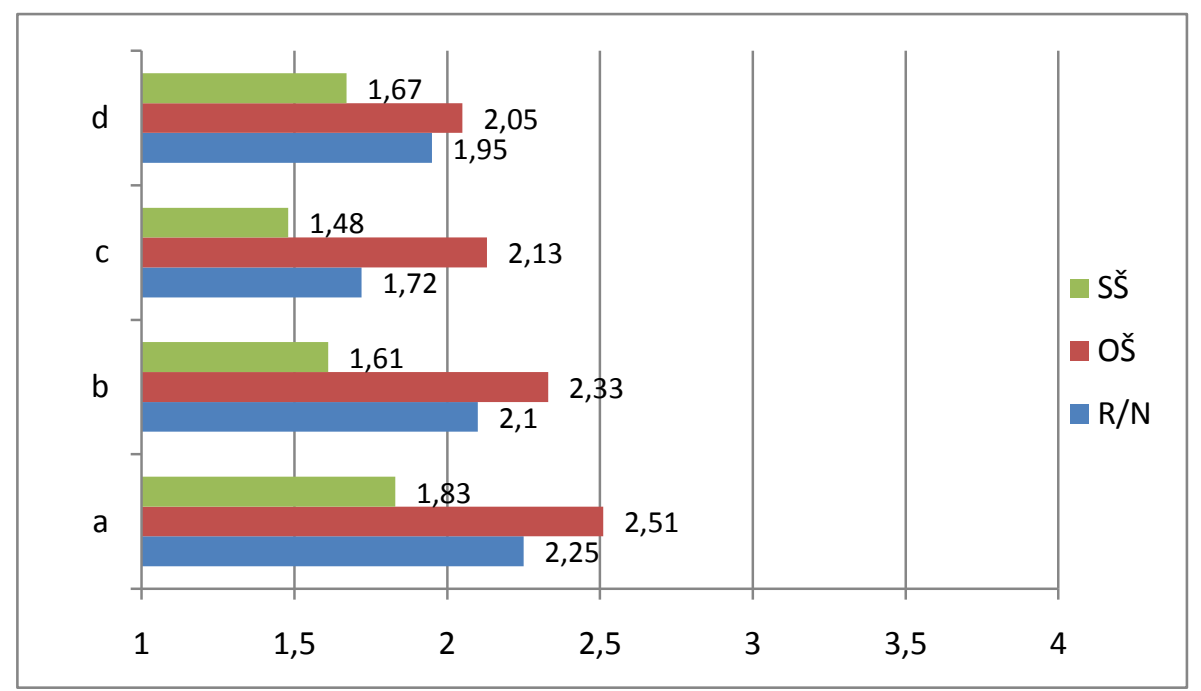

Graph 1. Average values of responses to questions from the first section

Under-average satisfaction was shown for statement (d) Creativity was appreciated while grading students (R/N 1.95; OŠ 2.13; Š 1.67). Intensity of examinees' attitudes for the first group of questions shows that negative attitude is present toward consumption of creativity during university studies, in all segments, from unfavorable teaching program, arid teaching and use of traditional methods of teaching and grading.

\section{Creativity in school}

In this section, the opinions of examinees about the state of creativity on school level will be presented. Examinees strongly agree about statement (a) School's equipment with necessary teaching aids is satisfactory (R/N 1.77; OŠ 1.76; SŠ 2.2). Examinees' attitudes reflect an objective image of poor material position in public schooling in Bosnia and Herzegovina. Examinees' attitudes about indicator (b) Creative teachers are well appreciated in school (R/N 1.63; OŠ 2.64; SS̆ 2.6) show that teachers in class teaching are dissatisfied the most. 


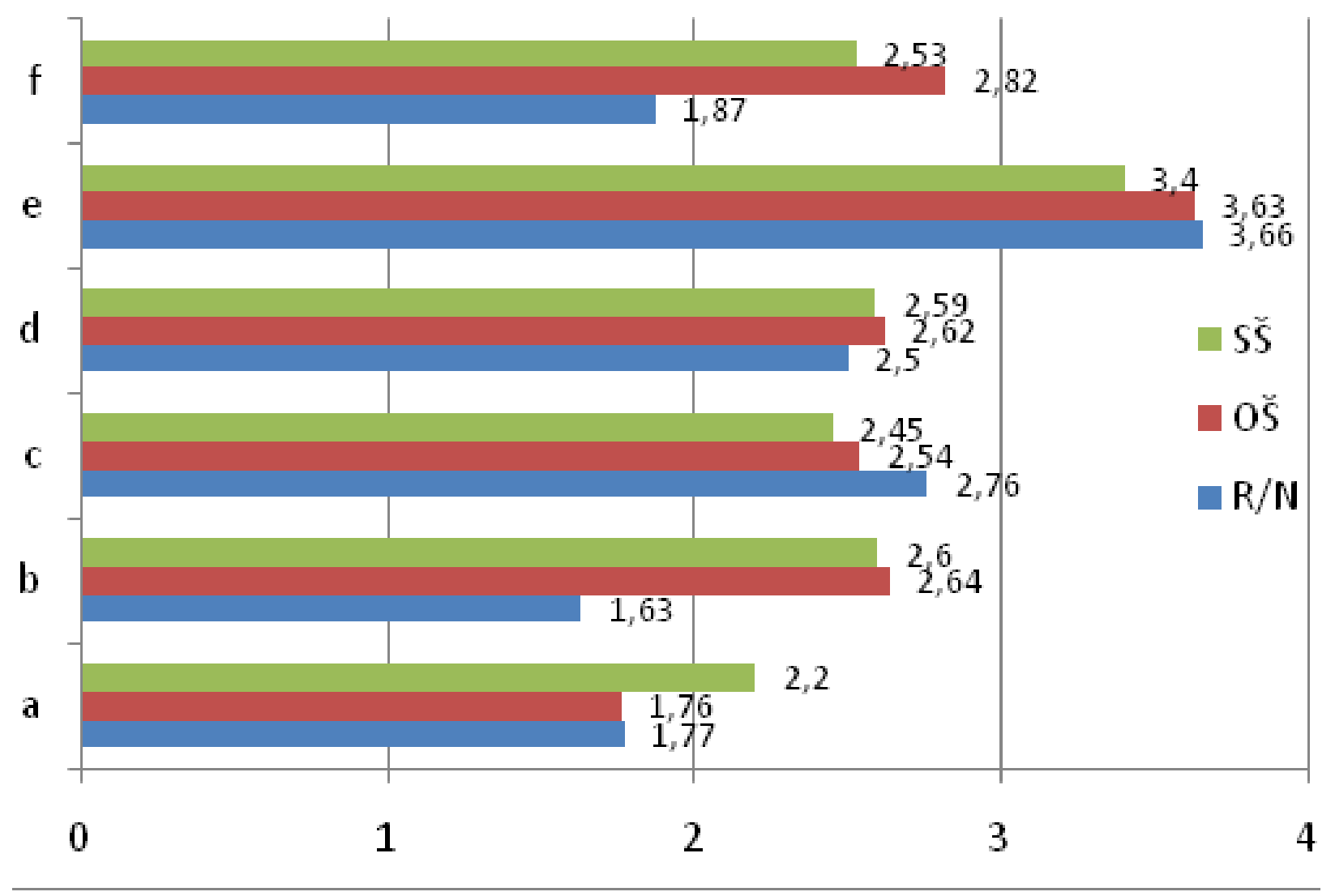

Graph 2. Average values for answers to questions from the second section

This certainly does not mean that they are not creative. In the circumstances of education in Tuzla Canton, it can be stated that precisely class teachers are the most trained for applying modern teaching methods, thematic planning, implementing the philosophy that "the child is in the center of activity", cooperative methods, critical thinking methods, etc., which have creativity at their core. According to this, examinees believe that the fact that they are creative is not appreciated enough in school culture. This can be confirmed based on intensity of examinees' attitudes for statement (c) School management takes creativity of teachers' class conduction into consideration for their evaluation (R/N 2.76; OŠ 2.54; SŠ $2.45)$, where average satisfaction with behavior of management was shown regarding their creativity. All examinees share almost unique intensity about statement (d) I am not motivated to be creative, because I am underpaid (R/N 2.5; OŠ 2.62; SŠ 2.59), which directly emerges from results of statements(b) and (c). On the other hand, it is clear that (e) Students prefer teaching through games with creative teaching aids to traditional manner of work, which is confirmed by a high level of agreement $(\mathrm{R} / \mathrm{N} 3.66$; OŠ 3.63; SŠ 3.4). Average values of intensity of attitudes to statement (f) Institute of Pedagogy regularly supports us in using contemporary working methods $(\mathrm{R} / \mathrm{N}$ 1.87; OŠ 2.82; SS̆ 2.53)show dissatisfaction with training by Institute of Pedagogy in Tuzla Canton, of class teachers more than Mathematics teachers in elementary and secondary schools, who are regularly present for expert advancement, probably because their number is several times smaller than class teachers.

\section{Creativity in teaching Mathematics}

Creativity in Mathematics teaching is very much present among examinees. This is shown by the level of intensities of attitudes toward claim (a) I have good experiences with using creativity in solving tasks in Mathematics teaching (R/N 2.71; OŠ $3.03 ; \mathrm{SS}$ 2.8). The greatest presence of creativity is in elementary school subject teaching. 
This can be justified with the fact that, based on experiences in other matters, it can be claimed that Mathematics textbooks for elementary school contain approaches which support and encourage students to be creative. This is confirmed by examinees' answers to the statement (b) Mathematics textbooks contain enough creative Mathematical tasks and didactic games (R/N 2.14; OŠ 2.08; ŠS 1,64), where it can be seen that secondary school teachers are very dissatisfied with textbooks. All examinees find it acceptable that (c) Entertaining tasks and creative games influence students' motivation in Mathematics teaching (R/N 3.15; OŠ 2.5; SŠ 3,25).

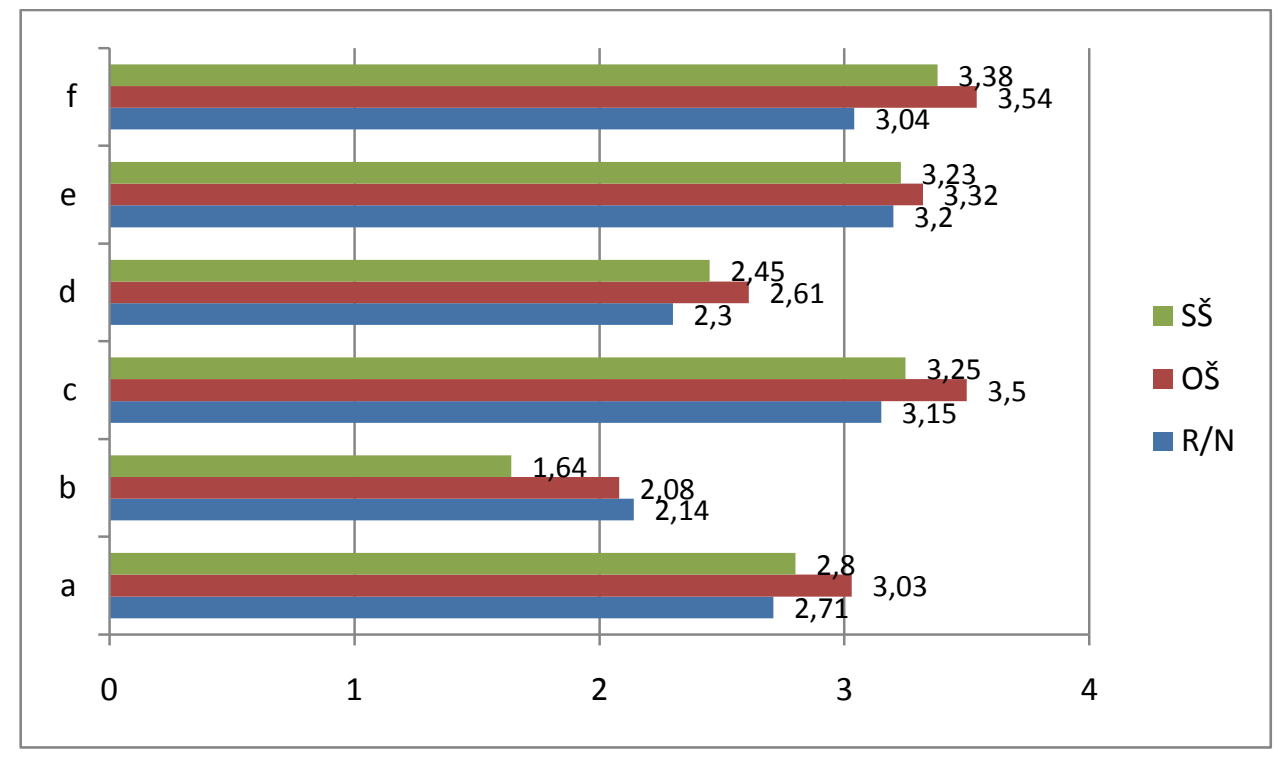

Graph 3. Average values of responses to questions from the third section

In relation to the following two components, examinees from the group of elementary school teachers have a more acceptable relation toward statement (d) In motivation section of the class I use modern teaching aids (R/N 2.3; OŠ 1.61; SŠ 2,45). They are also more convinced regarding statement (e) I believe that creative Mathematics tasks influence students' knowledge to become greater and more permanent (R/N 3.2; OŠ 3.32; SŠ 3,23), which concurs with the results from previous statement. The result is completely expectable for statement (f) in evaluating students, I take their creativity into consideration $(\mathrm{R} / \mathrm{N}$ 3.04; OŠ 3.54; SŠ 3,38). It can be noticed that relation toward creativity is more favorable in elementary school, which can be justified by the fact that those schools took a more aggressive approach toward project with thematics that includes creativity as a value.

\section{Examinees' recommendations for improvement}

Our intention was to ascertain several statements that may become measures for improving the status of creativity in education. The list of statements follows. Creativity should be one of indicators of successful teaching.

Expert advancement in school should focus on application of creative methods in teaching.

Schools need to be equipped with contemporary teaching aids.

More cooperation is need in school on the level of expert associations of teachers.

It is necessary to continuously improve expertise in application of creative methods in Mathematics teaching, in cooperation with Institute for Pedagogy.

Teaching curricula at graduate studies should be supplemented with subject disciplines which support creativity in teaching. 


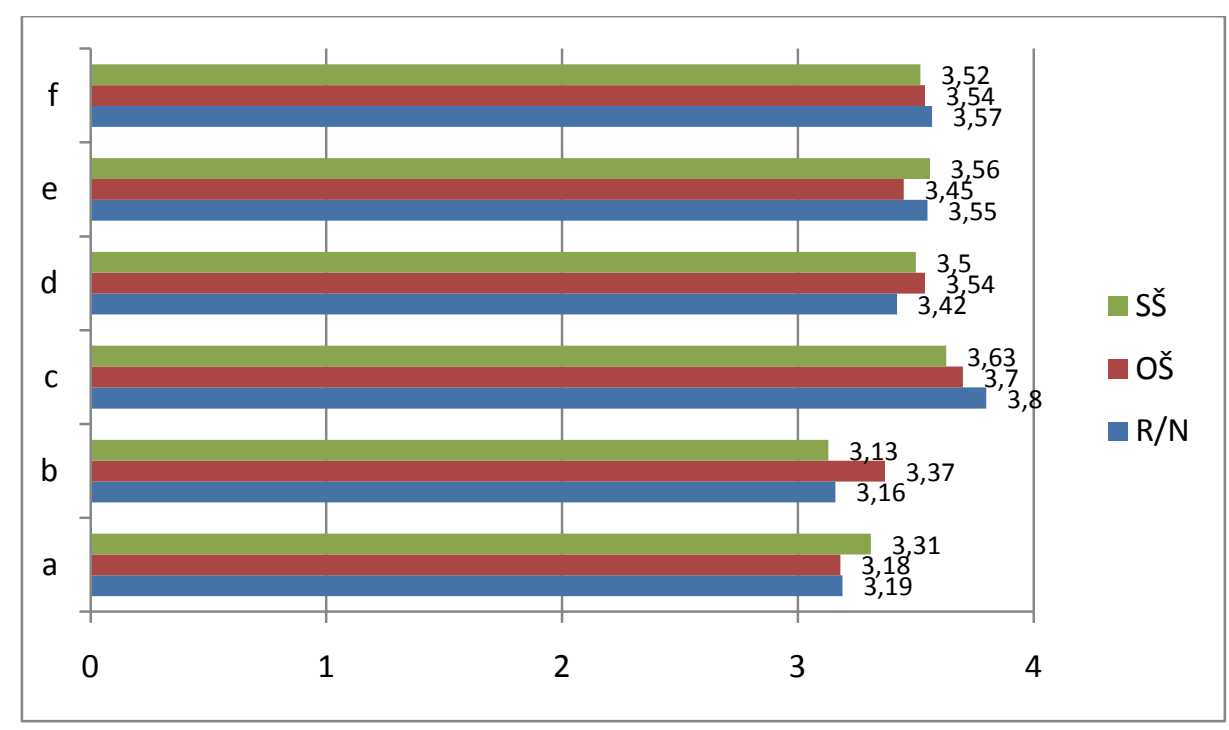

Graph 4. Average values of attitudes from section four

Average values of intensities of examinees' attitudes are presented in Graph 4. It can be concluded that examinees' agreement with all statements is high, and that average values of all attitudes are above 3 , or more precisely between 3.16 and 3.8. Highest agreement was achieved in question regarding acquiring contemporary teaching aids (R/N 3.8; OS̆ 3.7; SS 3.63). Examinees are more cautious when it comes to the suggestion that "creativity should be one of indicators of successful teaching" and that "expert advancement in school should focus on application of creative methods in teaching".

\section{CONCLUDING CONSIDERATIONS}

This research encompassed only several areas which cover creativity in school and Mathematics teaching. From the analysis of acquired data, the following may be concluded:

1.Intensities of examinees' attitudes regarding satisfaction with university studies' contribution to strengthening creativity (Graph 1) show that negative attitude was expressed toward creativity determinants, from university curriculum without disciplines that support and strengthen creativity, to lack of creative teaching and exercises without workshop approach and use of contemporary evaluation methods, all of which supports creativity. Secondary school examinees show significant difference in intensity in opinions of dissatisfaction with teaching curricula in education faculties (class teaching and Mathematics teaching) (SŠ-O $\breve{S}=-0.68$, $\mathrm{SS}-\mathrm{R} / \mathrm{N}=-0.42$ ). Similar relations apply for other statements. In all cases, the intensity of attitudes of Mathematics teachers in secondary school is less than the opinion of examinees in class and subject Mathematics teaching in elementary schools (Graph 1).

2.Average values of examinees' attitudes regarding statement that generate creativity on the school level (Graph 2) show that class teachers $(-0.43)$ and subject teachers of Mathematics in elementary schools (-0.44) are more dissatisfied with school's equipment than Mathematics teachers in secondary schools. This attitude of elementary school teachers can be explained with the fact that they are more involved in the process of teaching changes (project teaching, proactive methods of work, etc.) and they know about modern teaching aids, which their schools lack. It is obvious that Mathematics teachers in secondary schools show lesser need for moderns teaching aids. They are satisfied with traditional aids: schematic presentations, geometry accessories and models, etc. According to the opinion of class teachers, "creative teachers are not appreciated enough" on school level (RN-SŠ=-0.97). This is a consequence of traditionally unsuitable relation of subject teachers toward work of class teachers, their teaching norm, quality of work, etc. On the other hand, Mathematics teacher in elementary and secondary schools share the same opinion about the value of creative Mathematics teachers on the school level (OŠ-S $\breve{S}=+0,04)$. This is not the case when it comes to school management's relation toward teachers' creativity. 
Elementary school teachers have a more positive opinion than their colleagues in secondary school about the fact that their management pays more attention to teachers' creativity in evaluation process $(\mathrm{R} / \mathrm{N}-$ $\mathrm{S} \breve{S}=+0,31$; OŠ-S $\breve{S}=+0,09)$, which means that creativity as a value is more present in elementary school than in secondary school. Almost all examinees (subject teachers exhibit difference of 0.03) claim that they are not motivated enough to be creative. Furthermore, elementary school teachers are more aware that "student prefer teaching through playing, with use of creative teaching aids, to traditional manner of work" than secondary school teachers. Examinees have different attitudes about "support from Institute for Pedagogy for using contemporary work methods". Class teachers are very dissatisfied with that support. This can be explained through the fact that they are educated by non-government sector and know about that kind of support, which they do not receive from Institute for Pedagogy.

3.Based on indicators which generate relation toward creativity (Graph 3) in Mathematics teaching, teachers in elementary schools have better experiences in "using creativity in solving tasks in Mathematics" (SŠ +0.23$)$. According to examinees' opinion, class teachers and Mathematics teachers in elementary schools have a stronger attitude toward the statement that "school Mathematics textbooks contain enough creative Mathematical tasks and didactic games" than secondary school teachers $(\mathrm{R} / \mathrm{N}-\mathrm{S} \breve{S}=+0.50$; OŠ-SŠ $=+0.56$ ). This is also the researchers' attitude. Similar situation occurs for the statement that "fun tasks and creative games affect students' motivation in Mathematics teaching". Subject teachers of Mathematics have a more positive attitude for 0.25 points than secondary school teachers. This is to be expected, considering that the intensity of answers about "use of modern teaching methods" is stronger in elementary school teachers than in secondary school teachers $(+0.16)$. This was confirmed by answers to the statement "that creative Mathematical tasks affect students' knowledge to become greater and more permanent" (OŠ-S $\breve{S}=+0.09)$. In the end, the ratio of attitude intensities regarding grading students is natural - "their creativity is taken into consideration", which is again less favorable in the case of Mathematics teachers in elementary schools than in secondary schools $(+0.16)$.

Taking into account intensities of attitudes of all examinees regarding support for development of creativity in school, it can be noticed that their average values are between 1.48 and 2.5 on scale 1.00-4.00. In our case, certain dissatisfaction was shown with, for example:

Support during undergraduate studies, where almost all average values of attitudes from research section one, are below 2.25 of maximum 4.0;

School equipment with necessary teaching aids is not satisfactory (R/N 1.77; OŠ 1.76; SŠ 2.2),

Teachers' motivation for employing creativity (OŠ 2.62; SS 2.59), is low because they are underpaid (R/N 2.5; OŠ 2.62; SŠ 2.59),

Because of educative support by Institute for Pedagogy regarding use of contemporary work methods (R/N 1.87; OŠ 2.82; SŠ 2.53), and

School textbooks in Mathematics regarding support in sufficient number of creative Mathematics tasks and didactic games (R/N 2.14; OŠ 2.08; SŠ 1.64),

Experiences in using creativity in task solving in Mathematics teaching (R/N 2.71; OŠ 3.03; S Š 2.8).

This confirms the first hypothesis H1: creativity in schools does not have appropriate support for development.

On the other hand, in comparative analysis of examinees' attitudes in elementary and secondary schools, it has been determined that:

in elementary schools creative teachers are more appreciated than in secondary schools (OŠ 2.64; SŠ 2.6), management in elementary schools takes creativity in teaching into consideration during evaluation more than in secondary schools (OŠ 2.54; SŠ 2.45),

teachers in elementary schools have a stronger belief than secondary school teachers that their students prefer teaching through games with use of creative teaching aids to traditional way of work $(\mathrm{R} / \mathrm{N} 3.66$; OŠ 3.63; SŠ 3.4),

elementary school teachers are more satisfied with Mathematics textbooks which contain enough creative Mathematical tasks and didactic games than secondary school teachers (R/N 2.14; OŠ 2.08; S Š 1.64), in motivation part of class, elementary school teachers use modern teaching aids than secondary school teachers (OŠ 2.61; SS̆ 2.45),

elementary school teachers are more aware that creative Mathematical tasks influence students' knowledge, making it greater and more permanent (OŠ 3.32; SŠ 3.23), and

elementary school teachers are stronger in opinion that making creative Mathematical tasks influences students' knowledge, making it greater and more permanent (OŠ 3.32; SS̆ 3.23). 
The mentioned findings confirm the thesis that "relation toward creativity is more favorable in elementary, than in secondary schools in ", which confirms the second hypothesis $\mathrm{H} 2$.

\section{RECOMMENDATIONS}

The question of creativity in Mathematics teaching is an issue interesting for education public sphere. The problem of increasing students' interest for studying is closely connected to presence of creativity in work with students. It has been seen that it is much easier to talk about creativity than concretely find a way for its realization. We have shown that relation toward creativity is inapposite with all participants in education process, from university, education administration, agencies for supporting teachers' development, to school and teachers level, as "immediate manufacturers" in conducting teaching. Based on conducted research and experiences from teachers' of elementary and secondary schools hospitation, the following recommendation can be made for improving the relation toward creativity:

Teaching plans and curricula in graduate studies at university need to be updated with modules which support creativity in Mathematics teaching (i.e. creative and cooperative methods of work in Mathematics teaching, innovations and experiments in Mathematics teaching, motivation in Mathematics teaching, making creative tasks and innovations in grading, etc.).

In conducting Mathematics classes, including exercises, it is necessary to use various methods and forms of work that support creativity (students' attendance in classes at school, simulations, workshops, research, projects, heuristic teaching, beginner experiments in classes, etc.).

Creativity in conducting classes should be one of indicators in measuring quality of teachers' work.

Expert advancement programs on all levels (school, network of schools, Institute for Pedagogy, ministries, university) should be focused on development and use of creative methods in teaching.

Empower schools for creating projects with the aim or acquisition of necessary teaching aids.
Improve the work of expert Mathematics teaching associations in schools, with the aim of exchanging useful experiences regarding creativity in teaching.

Results of this research show that in the context of Bosnia and Herzegovina, relation toward creativity is not in a suitable place. Several possibilities and concrete activities for improving its position have been presented. The mentioned theoretical outlooks should be observed in accordance with Levin's saying that "Nothing is more practical than good theory" (Birzea, 2001:15). Without disregarding opinions of various authors, voices of teachers should not be ignored, and they prefer the theory that we should more energetically step forward from words to actions.

\section{REFERENCES}

Agić, H. (2011). Implikacije usavršavanja direktora na vođenje u promjenama. Tranzicija/Transition, Časopis za ekonomiju $i$ politiku tranzicije/Journal of Economic and Politics of Transition 13 ( 27), 10-20.

Amabile, T.M., Conti,R., Coon,H., Lazenby,J., and Herron, M. (1996). Accessing the Work environment for Creativity. The Academy of Manegement Journal 39 (5), 1154-1184. www. links.jstor.org

Bakovljev, M. (1997). Osnovi metodologije pedagoških istraživanja. Beograd: Naučna knjiga

Birzea, C. (2001). Obrazovne politike zemalja u tranziciji. Council of Europe Publishing I Pedagoški zavod. Bihać

Fullan, M. (2001). Leading in a culture of change, San Francisko: Jossey-Bass

Grković, M. (2012). Osobine kreativnih osoba. http://www.portalalfa.com (05.03.2015.)

Grković, M. (2014). Što znači potisnuta kreativnost i kako je osloboditi? http://www.portalalfa.com (11.03.2015.)

Kadum, V. (2011). Kreativnost u nastavi matematike, Izlaganje sa znanstvenog skua, Odjel za odgojne i obrazovne znanosti Sveučilišta Jurja Dobrile u Puli (Hrvatska), (3-10) www. hrčak.srce.hr/file/106642

Merriam, B. Sharan. (1998). Qualitative Research and Case Study Applications in Education. San Francisssco: Jossey-Bass. Mužić, V. (1999). Uvod u metodologiju istraživanja odgoja $i$ obrazovanja. Zagreb: Educa

Pinter Krekić, V. and Ivanović, J. (2013). Creativity Strategy for Mathematics Instruction. Croatian Journal of Education, Vol:15; No.2/2013,289-329 .

Ristić, Ž. (2006). O istraživanju, metodu i znanju, drugo izdanje. Beograd: Institut za pedagoška Istraživanja

Stoll, L., and Fink, D. (2000). Mijenjajmo naše škole. Zagreb: Educa 